\title{
Mobile Phones - Boon to Rural Social System
}

\author{
Ravinder Kaur Dhaliwal, Vister Joshi \\ Department of Extension Education, Punjab Agricultural University, India
}

\begin{abstract}
Mobile phone emerges as a great tool to enhance the system of transfer of information in agriculture, but its use is limited in certain areas. So, an effort in this paper has been made to enumerate the uses of mobile phones in Social System which is based on Axinn \& Thorat's model of rural social system. As in Production, farmers get timely information of weather forecasts, crop advisory. In Marketing and Supply, day to day information of commodity prices, market and other relevant information are available. Mobile learning can educate farmers. In governance, it emerges with a new concept of m-governance. And feedbacks through it can revolute research system. Primary data was also collected to know the opinion and preferences of farmers towards the use of mobile phones in agriculture. Data shows that farmers preferred information on marketing most, as it attained first rank. According to farmers, State Agriculture Universities are the most credible source of information while private agencies are least. Majority of farmers preferred 2-3 messages per day for fulfilling their information needs. They preferred SMS is the best way of providing information as they can read and save it for its future use. And finally, production is the most used area of Rural Social System among the farmers by mobile phones.
\end{abstract}

\section{Introduction}

Mobile phones have proven its usefulness in all sectors. Social networking by mobile telephony has opened the channel to enhance the living standard of rural dwellers. This has also become a symbol of progress. If rural telephony grows by $1 \%$ there will be an increase of $0.6 \%$ in Gross Domestic Product (GDP) showing the impact of growth of rural mobile telephony on Indian economy. Mobile Telephone is playing a very important role in fulfilling the information needs of farmers. The mobile phone based agricultural information services like IFFCO Kisan Sanchar Limited (IKSL) and Reuters Market Light (RML) are becoming popular in India and providing services through SMS and Voice messages about agriculture related information.

Of the next 250 million Indian wireless users, approximately 100 million (40 per cent) are likely to be from rural areas, and by 2012, rural users will account for over 60 per cent of the total telecom subscriber base. With over 300 million mobile subscribers, India is the second largest market, after China, in terms of subscribers. (Confederation of Indian Industries (CII) and Ernst \& Young, Report) [5].

The tele-density of the Punjab state of India is nearly 46 percent which is double the national average of 20 percent. The mobile phone is no longer just an audio communication tool but capable of providing additional integrated functions. The various features of mobile phone, which makes it versatile, are SMS, Voice messages, MMS, GPRS. Therefore an effort in this paper has been made to enumerate the uses of mobile phones in agriculture and opinion of farmers towards the use of mobile phones in agriculture.

\section{Tools Of Mobile Technology -“Mobile Technology Basket"}

The mobile phone is no longer just an audio communication tool but capable of providing additional integrated functions. The various features of mobile phone, which make it versatile, are:

SMS: The basic form of sending messages between mobile phones is a text message, or SMS, which is a network service available almost everywhere. SMS can be up to 160 characters, and are sent via an SMS centre to the recipient's phone via a signaling path. It is largely used for information based services. SMS has the maximum reach amongst the users, since all the mobile phones support SMS. The increased importance of SMS has also made content developers burn the midnight oil to come up with better and newer concepts and services. An added benefit of SMS is that it can still work even in weak cell phone coverage areas where voice would not. One does not have to travel long distances to access the information as is the case with email and internet. The information here is instant.

MMS: Multimedia messages can take longer text, graphics, photos, audio clips, video or any combination of these, with certain size limits. They are not available on all phones, or networks. USSD offers a menu system to make a lot of information 
available using SMS style technology and functionality and most networks support it.

GPRS: General Packet Radio Service is a technology that enables high speed wireless Internet and other data communications. Using packet switching, subscribers are always connected and always on-line, so services are easy and quick to access.

\subsection{Pillars of Mobile Based Service}

The growth of Mobile based Service is based on Access devices, Content, Technology and Infrastructure.

Access devices: Access devices play an important role in the usage. The lack of features like GPRS, GPS, Java in handsets make a number of features futile. Therefore the affordable availability of such features is a key factor in determining the size of the target audience to a large extent.

Content: Relevant content needs to be generated to play a significant role. Marketing the content in rural market is going to be all the more challenging. This would require right packaging and pricing of such service

Infrastructure: Infrastructure requirement needs to be met to harness the potential of different technologies. Setting up infrastructure especially in the rural areas is going to play a major role in the growth of service.

Technology: There are two aspects to technology. One is the technology platform itself and the second is the communication technology. On one hand technology platforms are independent of geography and are transportable across borders.

\subsection{Rationale to Use Mobile Telephony}

Mobile telephones have following advantages over other tools of communication:

Access. Penetration rate is ever increasing and even more have access through shared usage and ownership. Related to access is that mobile phones add the dimension 'anywhere and anytime': due to their mobility and that mobile phones are switched on most of the time, which opens up for new possibilities.

Reach. Again, due to its mobility and network infrastructure, mobiles can reach areas where there is no other ICT infrastructure (like internet, fixed lines).

Adoption. As mobile phones more and more become an integral part of people's lives, m-commerce and m-government will be the normal way of doing things. Further, there is an increasing public demand for mobility and easy access to services.

Interaction. Mobile phones make it possible for real-time, two-way dialogue as opposed to radio, brochures, posters, public speeches etc.
Costs. The relatively lower cost of mobile phone technology versus internet technology has lowered the entry barriers for poor people. Affordability is still a concern though somebody needs to pay for the infrastructure, communication and services.

Efficiency. Due to high access, its reach, good adoption and real-time interaction mobile phones offer efficient solutions to governments' communication challenges.

No other option. In developing regions with poor infrastructure, going mobile may be the only viable option.

\section{Application of Mobile Phone in Agriculture}

Application of usage of mobile phones in agriculture is discussed, which is based on the Axinn and Thorat components of typical rural social system [1]. Production, Supply, Marketing, Research, Governance and Education/Extension are the six major components of typical rural social system.

They further explained that all components are linked with each other. Each linkage has certain characters as Capacity (quantity of transactions over time), Fidelity (quality), Memory and recycling capability. So, there is a need of potential external linkage which has all these characters and mobile phone is one of the best options for it. The applications of mobile phone in agriculture based on components of rural social system are as follows:

\section{a. Application of mobile phones in agricultural production}

According to Axinn and Thorat, production includes the tillers of the soil, the manager of farming operations, and the land owners, along with the communities of which they are a part.

The application of mobile phones in production should be based on the information needs of the farmers. Farmers require the information from the time of crop planting as about high yielding crops, seed varieties etc, about the planting techniques, at harvesting about weather etc.

For better production, accurate and timely information is essential for making right decision. Many management decisions in modern farming require up to date global and local information, for example, weather forecasts and regional recordings of crop diseases and pests. It is also a fact that most farmers own a common mobile telephone with SMS (short messaging service) features. That is why mobile can easily provide this information to the ultimate users.

Reuters Market Light and IFFCO Kisan Sanchar Limited are providing the services on weather forecasting and crop advisory in association with Punjab Agricultural University to offer best in class advisory tips in the timeliest manner. 


\section{b. Application of mobile phones in marketing:}

Market Information Systems known as Market Intelligence Systems, Market Information Services or MIS, are information systems used in gathering, analyzing and disseminating information about prices and other information relevant to farmers, animal rearers, traders, processors and others involved in handling agricultural products.

Marketing today depends on information system, which provides adequate information about what people want, at what price, and who can supply it.

Today, IFFCO, REUTERS and other organizations are providing the information related to market. Farmers are in a dilemma as they have no information about market price, no negotiation power with traders and middlemen and finally no profit. That is why there is a need to provide the technology platform to improve communication among the farmers for aggregate crop information and to access market information.

\section{c. Application of mobile phones in Education/extension}

In education, mobile phones have come up with the concept of m-learning. The term "learning" or "mobile learning", has different meanings for different communities. Although related to elearning and distance education, it is distinct in its focus on learning across contexts and learning with mobile devices. Mobile learning is a sort of learning that happens when the learner is not at a fixed, predetermined location, or learning that happens when the learner takes advantage of the learning opportunities offered by mobile technologies [6]. In other words, mobile learning decreases limitation of learning location with the mobility of general portable devices.

M-learning is convenient in the sense that it is accessible from virtually anywhere. It is also collaborative; sharing is almost instantaneous among everyone using the same content, which leads to the reception of instant feedback and tips. In addition, this kind of learning is engaging and fun. Therefore, it is simple to utilize mobile learning for a more effective and entertaining experience.

\section{d. Application of mobile phones in supply}

Axinn and Thorat includes the individuals, organizations, and agencies that supply to the production component its inputs (such as seeds, fertilizers, and pesticides ) and the credit and other financial arrangements that makes it possible for supply to flow. Can mobile telephony improve commercial supply chains in developing countries?

IFFCO is a recent example which is using mobile technology in its supply chain. With its roots in cooperative, IFFCO's production is supply driven and not demand driven. Finally, mobile act as best solution for their requirements.

Moreover, through IKSL, they are providing services to farming regarding the use and availability of fertilizers, which enhance their supply system and farmers become capable to get the product at negotiated rates. Similarly, the other inputs can be promoted through mobiles and farmers will be in a better position to make an informed decision in selecting the inputs.

\section{e. Application of mobile phones in research}

Due to its versatility, mobile phones had become a powerful tool. There are number of ICT tools combined with mobile phones create a revolution in present generation. Research and related activities are easily possible with the use of mobile phones. Scientists can easily get the feedback from the farmers and research will become participatory.

\section{f. Application of mobile phone in governance}

During the past several years, there exist ample evidence that how mobile phones and the simple functions of voice and text messaging (SMS) had empowered citizens and affected the way citizens interact with each other and with the society as whole. So, a new concept evolved called mgovernance.

Kushchu and Kuscu defined m-government as a "strategy and its implementation involving the utilization of all kinds of wireless and mobile technology, services, applications and devices for improving benefits to the parties involved in egovernment including citizens, businesses and all government units"[3].

There is a very wide range of potential related governance services which can be delivered and communicated via mobile phones, including services relating to health care, agriculture, education, employment, transportation law and order, tax, judicial and legal systems, etc. Mobile payments, now available in all East African countries, opens up for even greater opportunities and possibilities for transactions such as bill, loan, fine payments and mobile payments for a variety of public services like transport and school fees [2].

\section{Rural Socio-economic benefits}

Mobile telephony effectively reduces the distance between individuals and institutions, making the sharing of information and knowledge easier and more effective. Social networks can be strengthened and individuals empowered through use of their handset. Moreover, Mobile telephony offers some unique opportunities, as:

- It provides global communication channel to rural communities

- It extends the impact of established rural media, 
such as rural radio

- It helps in making the local content available to the rural people.

- It makes rural services more efficient (logistics, coordination, etc) and cost-effective.

These benefits are amplified by the fact that the spread of mobile technology in some rural regions has occurred much faster as compared to other information and communication technologies.

\section{Limitations of the technology}

Though mobile telephones have lot of advantages but like all technologies it has some limitations too. These limitations are:

- High costs, especially for new generation sets.

- Limited network coverage and low bandwidth in some rural areas. But in Punjab there is no limitation regarding this.

- Limited capacity of rural people to use the technology, particularly for more complicated applications for images, GPS data, etc.

- Low awareness of the technology for educational purposes.

- Technology limitations such as character limit for SMS (impact on complex information sharing), and the lack of available non-Roman scripts.

\section{Opinion of the Farmers}

A sample survey to know the preferences of farmers regarding the usage of mobile phones in agriculture was conducted on 50 progressive farmers of PAU Kisan Club (Regd). Nearly 200 farmers regularly attend the monthly meetings. Random sample of 50 farmers was drawn from these club members. The farmers were interviewed personally with the help of the structured schedule. Analysis of data was done through frequencies, percentage, mean score and rank.

6.1. Preference for the type of information. Preferences of the respondents regarding the type of information required is placed in Table 1:

Table 1. Preference for the type of information required

$$
\mathbf{n}=\mathbf{5 0}
$$

\begin{tabular}{|l|l|l|}
\hline Type of information & $\begin{array}{l}\text { Average } \\
\text { mean score }\end{array}$ & Rank \\
\hline Production & 4.16 & $2^{\text {nd }}$ \\
\hline Supply & 2.84 & $4^{\text {th }}$ \\
\hline Marketing & 4.76 & $1^{\text {st }}$ \\
\hline Research & 2.76 & $5^{\text {th }}$ \\
\hline Governance & 2.68 & $6^{\text {th }}$ \\
\hline Education/Extension & 3.8 & $3^{\text {rd }}$ \\
\hline
\end{tabular}

Marketing was preferred by maximum number of respondents and was placed at rank one based on the mean score. This may be due to the reason that farmers lack market information and they are unable to reap the maximum benefits. Information related to production as weather forecast and crop advisory received second rank. Education and research related information was placed at third rank. And very few farmers demanded governance related information as it was placed at the last rank.

6.2. Credibility of the sources. All the respondents considered State Agricultural Universities (SAU) as the most credible source of information and placed it at the first rank. Private agencies were least credible source of information as it received forth rank as shown in Table 2.

Table 2. Credibility of the source of Information according to respondent farmers

\begin{tabular}{|l|l|l|}
\hline Sources & $\begin{array}{l}\text { Mean } \\
\text { score } \\
\text { value }\end{array}$ & Rank \\
\hline SAU's Agriculture & 4.00 & $1^{\text {st }}$ \\
\hline $\begin{array}{l}\text { State } \\
\text { Department }\end{array}$ & 2.76 & $2^{\text {nd }}$ \\
\hline Cooperatives & 1.88 & $3^{\text {rd }}$ \\
\hline Private agencies & 1.36 & $4^{\text {th }}$ \\
\hline
\end{tabular}

State Agriculture Department and Cooperatives were placed at second $\&$ third rank respectively.

6.3. Per day number of messages required. The information regarding per day number of messages required is given in Table 3.

Table 3. Per day number of messages suggested by farmers

\begin{tabular}{|c|c|c|}
\hline No. of messages/per day & $\mathbf{F}$ & \%age \\
\hline $2-3$ & 35 & 70 \\
\hline $3-5$ & 10 & 20 \\
\hline More than 5 & 5 & 10 \\
\hline
\end{tabular}

Seventy per cent of the respondents required 3-5 messages per day related to agriculture information. Two-three messages were preferred by twenty Per cent of the farmers. Only ten per cent respondents preferred 5 or more messages per day. All the respondents reported that the messages should be in their local language.

6.4. Preference for type of message. As many as 80 per cent of the farmers suggested that SMS is the best way to provide information as it can be saved in the message box and can be read later on. Only 20 per cent farmers suggested that voice messages are best in fulfilling their information need because it is difficult for them to read (Table 4.) 
Table 4. Preference for type of messages suggested by farmers

\begin{tabular}{|l|l|l|}
\hline Type of message & F & \%age \\
\hline SMS & 40 & 80 \\
\hline Voice Message & 10 & 20 \\
\hline
\end{tabular}

And majority of farmers were unaware about MMS and GPRS facilities as their mobile phones were devoid of this technology.

\subsection{Extent of use of mobile phones in all the areas of Rural Social System}

Extent of use of mobile phones in all areas of Rural Social System is shown in Table 5.5. Production is the major area of use by mobile phones among the farmers with the mean score of 0.57 and rank first while area of governance is second most used area, with the mean score of 0.46. Area of marketing, supply, education $\backslash$ extension, and research are ranked third, fourth, fifth and sixth with mean score of $0.35,0.34,0.02$ and 0.01 respectively.

Table 5. Extent of use of mobile phones in all the areas of Rural Social System

$$
\mathbf{n}=50
$$

\begin{tabular}{|l|l|l|}
\hline Aeas of use & $\begin{array}{l}\text { Mean } \\
\text { score }\end{array}$ & Rank \\
\hline Production & 0.57 & 1 \\
\hline Marketing & 0.35 & 3 \\
\hline Supply & 0.34 & 4 \\
\hline Education\Extension & 0.02 & 5 \\
\hline Research & 0.01 & 6 \\
\hline Governance & 0.46 & 2 \\
\hline
\end{tabular}

\section{Recommendations}

- State Agricultural Universities should provide these services to the farmers as majority of farmers exhibited SAUs as the most credible source of information.

- Awareness should be created among the farmers about the functions and use of mobile phones, for its full benefit.

- Mobile phones should be used for educating the farmers.

- Government should provide the subsidized phones to the farmers with necessary functions.
- The facility of free/subsidized agricultural messages should be provided to the farmers.

\section{Conclusion}

Mobile phones can help farmer in making right decision at right time during the production and also enable him in gathering, analyzing and disseminating information about prices during the marketing and supply of their crop. Moreover, it provides two way channels, which is useful in research as well as in better governance. Mobile phones can also help in educating farmers. Ultimately Mobile phones can be a potential external linkage within all the components of rural social system given by Axinn and Thorat.

All State Agriculture Universities (SAU) are focusing on production technology but the data shows that farmers preferred information on marketing. And SAU's are most credible source of information while private agencies are the least credible. Per day 2-3 messages were considered enough to fulfill their information needs as suggested by 70 percent farmers while 80 percent farmers preferred SMS as the best source of providing information as it can be saved for future. Production is the most used area of Rural Social System among the farmers with the mean score of 0.57 while research is the least used area. Though few private agencies are providing agriculture information but for the sustainable development SAU's should take steps towards the use of mobile phones in agriculture.

\section{References}

[1] Axinn and Thorat, (1972) Modernizing World Agriculture. Pp 7-11. Oxford \& IB Pub. Co, New Delhi.

[2] Beardon H., (2009) How mobile technologies can enhance Plan and partners work in Africa, www.plan.fi (Accessed 29 October, 2009).

[3] Kushchu and Kuscu, (2004) cf: Hellstrom J (2008) Mobile Phones For Good Governance-Challenges and Way Forward, (Accessed 3 November,2009).

[4] Mobile Learning in India, www.upsidelearning.com, (Accessed 1 November, 2009).

[5] Tripathi G., (2009) India: The Impact of Mobile Phones, impact-of-mobile-phones-on-farmers (Accessed 28 October, 2009).

[6] Web definitions for M-learning, en.wikipedia.org (Accessed 1 November, 2009). 